\title{
EFFECT OF PURDUE IMPROVED CROP STORAGE (PICS) BAGS ON PROTEASE INHIBITORS ACTIVITY OF STORED BEANS (PHASEOLUS VULGARIS)
}

\author{
DOMINIQUE SAVIO NKUNDA*
}

*Food Processing Enterprise, Rwanda Institute for Conservation Agriculture (RICA), Bugesera District, Rwanda

\section{ABSTRACT}

The common bean is a versatile crop that plays an indisputable role in human nutrition and food security while providing proteins, carbohydrates, and other important nutrients. It is rightly called the meat for the poor. However, as all legumes in general, they contain several antinutrients which must be removed or deactivated prior to utilization as food. In addition, during storage, they develop the Hard-To-Cook phenomenon which, not only hinders their nutritional value, but also impacts on the forestry in developing countries where the firewood is the main source of energy used for cooking.

In this project, freshly harvested beans were stored for 2 months in Purdue Improved Crop Storage and propylene woven bags, then tested for antiprotease activity on bone gelatin as substrate. The protease used was the bromelain extracted from pineapple peels.

The protease inhibitors extracted from the Purdue Improved Crop Storage and the propylene stored beans inhibited the bromelain respectively by 10 and $20 \%$. The kinetics of inhibition resembled that of a mixed type, implying that different binding sites for bromelain and bean extracted inhibitors were involved.

It was then concluded that Purdue Improved Crop Storage bags were better than propylene woven bags at keeping bean proteins availability during storage.

KEYWORDS: Dry beans, PICS bags, PP woven bags, protease, inhibitors, bromelain, gelatin, storage

Received: Dec 12, 2020; Accepted: Jan 02, 2021; Published: Feb 05, 2021; Paper Id.: IJASRFEB20216

\section{INTRODUCTION}

The common bean (Phaseolus vulgaris) is a versatile crop, and the world production is increasing from the past 60 years. From $11 \times 10^{6}$ tons in 1961 it is now above $30 \times 10^{6}$ tons. The large producers are Asia $\left(14.6 \times 10^{6}\right.$ tons $)$, the

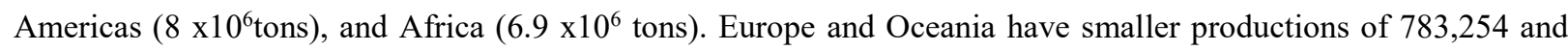
32,569 tons, respectively. The overall world yield increased from 7,578 to 8,823 tons/ha in the last 20 years but remained below 9 tons per ha. High yield increase was observed in Europe (12,000 to 18,000 tons/ha). The overall bean area harvested increased, due to increase in Africa $\left(4.4 \times 10^{6}\right.$ to $7.5 \times 10^{6}$ ha) and Asia $\left(11 \times 10^{6}\right.$ to $19 \times 10^{6}$ ha). The change of harvested area was too little in the Americas $\left(812 \times 10^{3}-953 \times 10^{3}\right.$ ha $)$, Europe $\left(400-413 \times 10^{3}\right.$ ha and Oceania (52-37 x10 $10^{3}$ ha) (FAOSTAT database, 2020).

As a source of proteins, beans are an alternative to the meat for the poor. Storage proteins comprise about $35 \%$ of dry seed weight and are essential in germination as a source of nitrogen (Mori et al, 2004). The phaseolin is the main storage protein in beans, though it can display a high diversity, depending on cultivars and geographic 
origins (De La Fuente1 et al, 2012). A recent study on different varieties in Latin America (Oliviera et al, 2017) has shown that raw beans have a variably high concentration of albumins, globulins, prolamins and glutelins that could each go as high as $1.2-14 \mathrm{mg} / \mathrm{g}$, depending on the variety.

The proteins are broken down into smaller polypeptides or single amino acids before utilization through digestion or seed germination. Proteases are enzymes that catalyse this biologically important change. Proteases are essential to the maintenance and the survival of organisms and play key roles in biological processes. Indeed, they are mediators of signal initiation, transmission, and termination in many of the cellular events (Habib and Khalid, 2007). However, when overexpressed or present in high concentrations, proteases are potentially damaging and need to be strictly regulated and controlled (Habib and Khalid, 2007). That is the role of proteases inhibitors widely found in biological systems and in stored seeds.

Enzyme inhibitors can give desirable benefits when slowing down harmful changes. For example, alpha-amylase and glycosidase inhibitors in common white beans were proven to slow carbohydrates absorption with, consequently, a positive impact on blood glucose levels and weight loss (Barrett and Udani, 2011). Recently, the efficacy of white kidney bean extract was compared with metformin $(100 \mathrm{mg} / \mathrm{kg})$ and atorvastatin $(10 \mathrm{mg} / \mathrm{kg})$ in mice. Bean extract reduced the body weight overtime, and lowered glycaemia, triglycerides, and cholesterol (Micheli et al, 2019).

In plants, proteases inhibitors are one of the defence strategies to combat predators like phytophagous insects and microorganisms by interfering with their digestive process (Habib and Khalid, 2007). The defensive capabilities rely on inhibition of proteases present in insect guts or secreted by microorganisms, causing a reduction in the availability of amino acids necessary for their growth and development (Lawrence and Koundal, 2002). Predators induce several internal signals from the wounded tissues, perceived in undamaged tissues, which thereafter produce different defense compounds. These bioactive plant defense compounds may repel or intoxicate the predators, while defense proteins often interfere with their digestion (Fürstenberg-Hägg et al, 2013).

The storage has an impact on the quality of common dry beans and the most obvious change is, undeniably, the Hard-To-Cook phenomenon. The storage affects the content of proteins, phytates, tannins and calcium (Mariotto-Cesar et al, 2013). Previous results (Nkunda, 2018) have shown that a two-month storage of common beans significantly reduces the total polyphenol content, and the reduction was greater in Purdue Improved Crop Storage (PICS) bags (50\%) than in polypropylene (PP) woven bags (44\%).

It is known that the efficiency of the hermetic storage like PICS bags relies, among other things, on the oxygen sequestration for storage pests like bruchids and beetles, the temperature, the relative humidity, and the level of infestation (Askey et al 2019; Navarro, 2012). In Africa, PP woven bags used as packaging for various food items are cheaply finding a second life in the storage of grains including dry beans.

The objective of this research was to investigate the effects of dry bean storage on the protease inhibition and to compare these effects in PP woven and PICS bags.

\section{MATERIALS AND METHODS}

\section{Source of Materials}

Pineapple peels (Ananas cosmosus) were collected from the pineapple unit of Inyange Industries (Kigali-Rwanda) and kept 
refrigerated at $4^{\circ} \mathrm{C}$ for less than 2 days before use. Cow bones were collected from Nyabugogo abattoir (Kigali-Rwanda), washed, and treated with warm water at $38-40^{\circ} \mathrm{C}$. PICS bags and PP woven bags were purchased respectively from ECOPLAST (Kigali-Rwanda) and the open market. PICS bags are usually sold in 2 sizes, for $50 \mathrm{~kg}$ and $100 \mathrm{~kg}$ grain storage. The 100-kg bags were cut into small bags and well-sealed with an electric bag heat sealer to store $2 \mathrm{~kg}$ of grain. PP woven bags are originally used for rice packaging and reused for different storage purposes.

Freshly harvested beans $(25 \mathrm{~kg}$ ) of season A (February 2016) were purchased from a local market and the half was kept by lots of $2 \mathrm{~kg}$ in PICS bags prepared as explained above, while the other half was kept in one PP woven bag. All of them were stored at room temperature (around $\left(25^{\circ} \mathrm{C}\right)$ in a dry place for 2 months.

\section{Method}

In this experiment, the protease used was the pineapple bromelain and the substrate was the cow bone gelatin. For the bromelain extraction, the pineapple peels were finely ground in a blender and filtered on a filter paper Whatman grade 1. The filtrate was centrifuged at $10,000 \mathrm{~g}$ for $20 \mathrm{~min}$ at $4^{\circ} \mathrm{C}$ to remove insoluble materials. The bromelain precipitation was performed by adding ethanol $98 \%(\mathrm{w} / \mathrm{w})$ at $0^{\circ} \mathrm{C}$ dropwise until the desired proportion of $10 / 90 \%(\mathrm{v} / \mathrm{v})$ was reached (Martins et al, 2014).

The gelatin was extracted from cow bones following the methodology described by Mariod et al (2011), Liu et al (2011), and by Shyni et al (2014). Cow bones were washed and treated for 10 min with water at $38-40^{\circ} \mathrm{C}$. Bones were then crushed into small pieces, soaked for 2 hours in NaOH.0.1N at ambient temperature (ratio bone/solution of 1:10, w/v), changing the alkaline solution every 1 hour. Alkaline-treated bones were washed with tap water until neutral or faintly basic $\mathrm{pH}$. They were then soaked in $0.2 \mathrm{M}$ acetic acid with a bone/solution ratio of 1:10 (w/v) for $24 \mathrm{~h}$ with gentle stirring at $4^{\circ} \mathrm{C}$, changing the acidic solution every $12 \mathrm{~h}$. Acid pre-treated bones were next washed with tap water until neutral $\mathrm{pH}$ of wash water, then completed with distilled water. The final extraction was done with distilled water at $45^{\circ} \mathrm{C}$ for $12 \mathrm{~h}$ with a bone/water ratio of 1:10 (w/v) and the clear extract obtained was filtered through a Buchner funnel with Whatman filter paper No 4. The fat was separated by allowing the mixture to settle in a decanter funnel and the lower phase of gelatin extract to flow out in a container. The gelatin extract was concentrated by evaporation under vacuum at $5^{\circ} \mathrm{C}$ and the concentrated viscous solution was freeze-dried at $-55^{\circ} \mathrm{C}$ for 2 hours at $0.01 \mathrm{mbar}$.

The protease inhibitors were extracted from PICS and PP woven bag stored beans as described by Liu and Markakis (1989). For this, dry beans were ground and sieved on a 50-mesh screen. The half of the sample was extracted for $30 \mathrm{~min}$ with $50 \mathrm{ml}$ of distilled water with mechanical shaking at $200 \mathrm{rpm}$. The sample suspension (10 ml) was destabilized by an addition of $10 \mathrm{ml}$ of the assay buffer and shaking 2-3 min before filtering on a Whatman No.2 paper. The filtrate was diluted with water to the point where $1 \mathrm{ml}$ gave $30-70 \%$ bromelain inhibition.

The bromelain inhibition was tested on 3 replicates following the Gelatin Digestion Unit Analytical Method developed by the Enzyme Development Corporation, 21 Penn Plaza, New York, NY 10001 (EDC, 2011). For this, 3 series of bromelain activity measurements were conducted successively, first with the gelatin substrate and bromelain extract alone, secondly, with added antiprotease from PICS-stored beans, and finally, with added antiprotease from PP woven bag stored beans. The results were recorded as the mean of the 3 measurements and the related standard deviations (SD). In the 3 series of experiments the increasing concentrations of gelatin substrate used were $0.05,0.10,0.20,0.30,0.40$ and 0.50 $\mathrm{g} / \mathrm{ml}$. The bromelain activities of the PICS and PP woven bag stored beans were compared to that of the bromelain alone 
through the curve of protease activities plotted against the gelatin substrate concentration. The Lineweaver-Burke graph was drawn by plotting the inverse of the bromelain activity against the inverse of the gelatin concentration (Saboury, 2009).

\section{RESULTS AND DISCUSSIONS}

When the bromelain activities were plotted against the gelatin concentration an increase was observed for all cases up to constant maximum values at around $0.4 \mathrm{~g} / \mathrm{ml}$ of gelatin. With inhibitor the maximum bromelain activity dropped from 20 to 18 and $16 \mathrm{GDU} / \mathrm{g}$ respectively for PICS and PP bag stored beans (Figure 1). This represents inhibitions of 10 and $20 \%$ respectively. In reversible inhibitions, which are the common case, inhibitors form noncovalent interactions with various parts of the enzyme surface and can be easily reversed (Saboury, 2009).

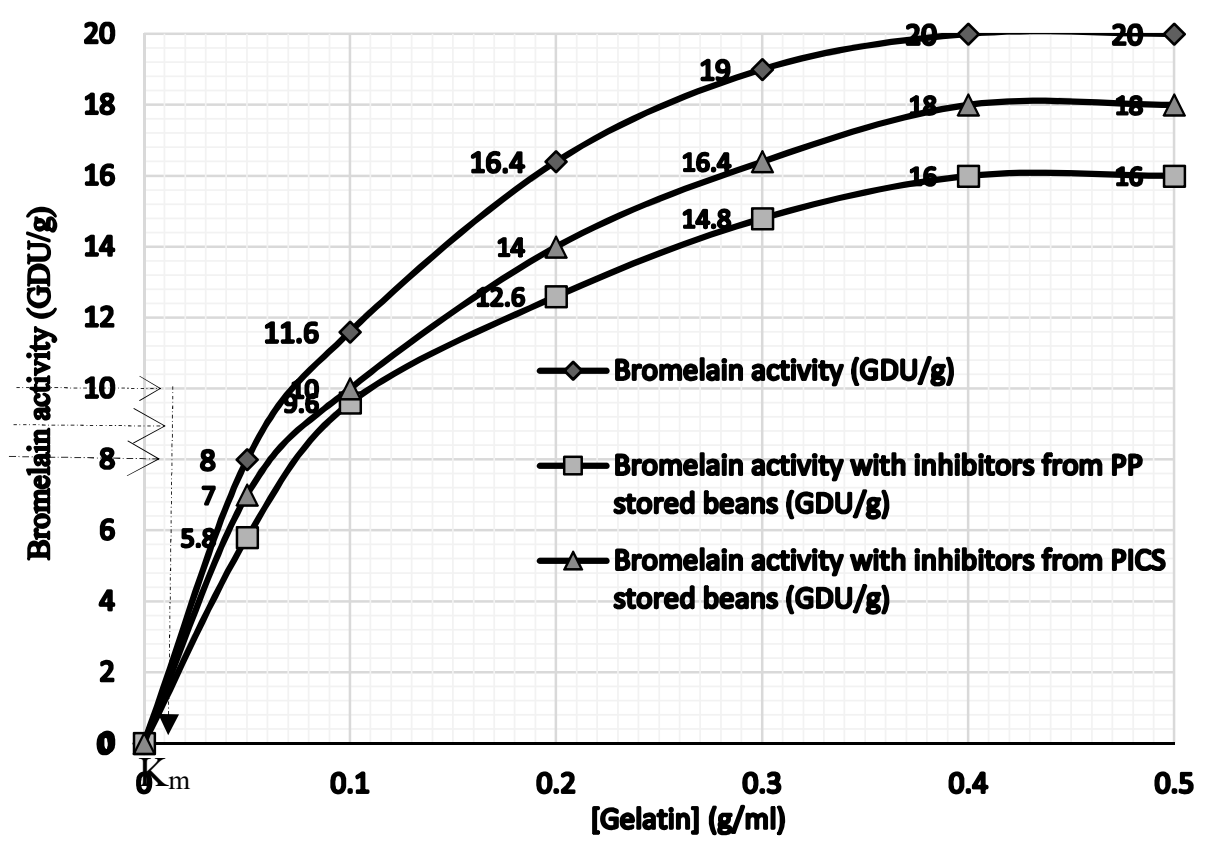

Figure 1: Bromelain activity on Gelatin with and without inhibitors extracted from PICS and PP woven bag stored beans.

The increase of the protease activity with the substrate concentration is consistent with the traditional enzyme theory of enzyme binding on specific sites of the substrate to form a complex that will ultimately lead to the product and the release of the enzyme. The enzyme becomes then ready for another cycle of binding and product release (Figure 2). In this model, the limited number of binding sites of the bromelain justifies the existence of the plateau.

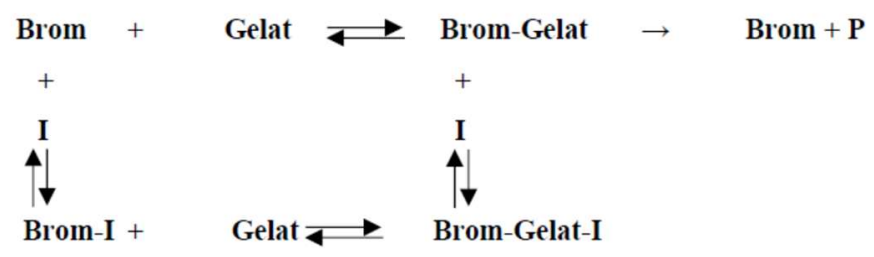

Figure 2: Mechanism of bromelain inhibition by inhibitors extracted from stored beans (Adapted from Saboury, 2009). 
The mechanism of inhibition can be investigated through the pattern of the chart. The half maximum bromelain activity without inhibitors $(10 \mathrm{GDU} / \mathrm{g})$ corresponds to the graphical gelatin concentration of approximately $0.075 \mathrm{~g} / \mathrm{ml}$ (Figure 1). This value is known as the Mickaelis-Menten's constant $\left(\mathrm{K}_{\mathrm{m}}\right)$.

The Lineweaver-Burk plots of (Bromelain activity) ${ }^{-1}$ or $\mathrm{V}^{-1}$ versus [Gelatin] ${ }^{-1}$ (Figure 3) in the absence and presence of bean inhibitors in different fixed concentrations intersect each other over the negative $\mathrm{X}$-axis. This is a characteristic of a mixed type inhibition and both $\mathrm{K}_{\mathrm{m}}$ and $\mathrm{V}_{\max }$ change. The plot without inhibitors intersects the X-axis theoretically at $-1 / \mathrm{K}_{\mathrm{m}}$. It is unlikely that the bromelain and the bean inhibitor will compete for binding the same site of the gelatin. Binding different sites of the substrate opens the possibility of a noncompetitive inhibition. On the other hand, the substrate and the inhibitor may attach simultaneously different sites of the enzyme, the affinity of one affecting that of the other. This results then in a mixed type inhibition.

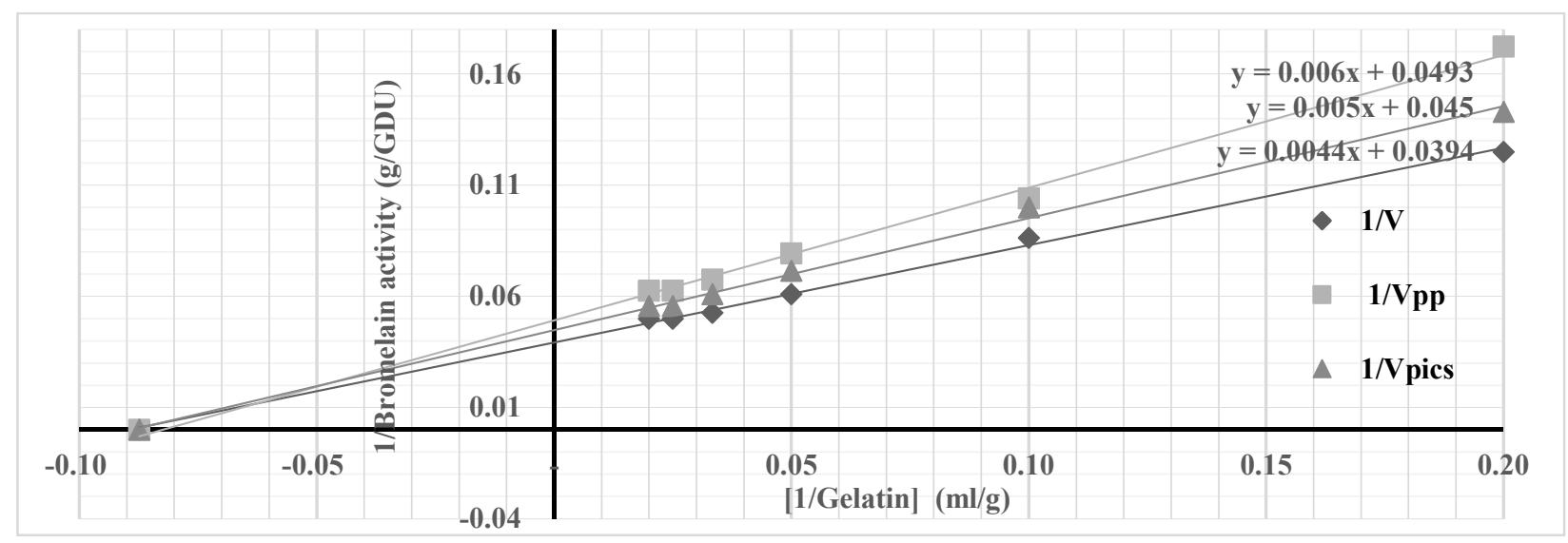

Figure 3: Lineweaver-Burk plot of protease inhibition of stored bean extracts on gelatin.

The protease inhibition is considered not only as protease regulation mechanism against potential damaging overexpression, but also as a defense strategy of the plant against insects and pathogenic organisms ( Fürstenberg-Hägg et al, 2013;Habib and Khalid, 2007; Lawrence and Koundal, 2002). The results show that the protease inhibition was higher in the PP woven bag than in the PICS stored beans and yet no single storage pest was observed during the storage, which could trigger the defense mechanism in the PP woven bag stored beans. How can this overexpression of protease inhibition be explained in PP woven bag stored beans? One of the possible answers is that the gas exchange with the environment and the resulting erratic conditions came as an offense that triggered a higher response of the PP woven bag stored beans. On the contrary the beans stored in PICS bags were somehow protected against adverse change from the environment. The impact of the protein inhibition on the protein availability and the nutritional value will depend on the thermal stability of inhibitors. Further research is needed to compare PICS and PP woven bag storage on their impact on the seed germinability.

\section{CONCLUSIONS}

Stored beans develop protease inhibitors. The mechanism of bromelain inhibition is of mixed type kinetics. The protease inhibition activity is higher in PP woven than in PICS bag stored beans and this can be attributed to an internal defense mechanism against environmental adverse conditions. Beans stored in PICS bags seem to be protected against the 
development of the protease inhibition. The protease inhibition affects obviously the nutritional value of stored beans. Further research is needed to investigate the effects of PICS and PP woven bags on the future germinability of stored seeds.

\section{REFERENCES}

1. Askey, J.; Bern, C.; Brumm, T. and Coats, J. (2019). Oxygen demand of bean bruchids (Acanthoscelides obtectus Say). J. Stored Prod. Postharvest Res. Vol. 11(2), pp. 8-14, July-December 2020.

2. Barrett, M.L., Udani, J.K. (2011). A proprietary alpha-amylase inhibitor from white bean (Phaseolus vulgaris): A review of clinical studies on weight loss and glycemic control. Nutr J 10, 24 (2011). Retrieved December 28, 2020 from https://login.research4life.org/tacsgr1doi_org/10.1186/1475-2891-10-24.

3. De La Fuente1, M.; López-Pedrouso, M.; Alonso, J.; Santalla, M.; De Ron, A.M.; Álvarez, G. and Zapata, C. (2012). InDepth Characterization of the Phaseolin Protein Diversity of Common Bean (Phaseolus vulgaris L.) Based on TwoDimensional Electrophoresis and Mass Spectrometry. Food Technol. Biotech. 50 (3) 315-325 (2012).

4. EDC. (2011). Gelatin Digestion Unit Analytical Method. Retrieved December 18th, 2020 from http://www.enzymedevelopment.com/wp-content/uploads/2011/10/Gelatin-Digestion-Unit-GDU.pdf.

5. Food and Agriculture Organization of the United Nations. (2018). FAOSTAT Database. Rome, Italy: FAO. Retrieved December 15, 2020 from http://www.fao.org/faostat/en/\#data/QC.

6. Fürstenberg-Hägg, J.; Zagrobelny, M. and Bak, S. (2013). Plant Defense Against Insect Herbivores. Int. J. Mol. Sci. 2013, 14, 10242-10297; doi:10.3390/ijms140510242. DOI: 10.5897/JSPPR2019.0295.

7. Habib, H. and Khalid, M.F. (2007). Plant protease inhibitors: a defense strategy in plants. Biotech. Mol. Biol. Rev. Vol. 2 (3), pp. 068-085.

8. Irwandi, J., Faridayanti, S., Mohamed, E. S. M., Hamzah, M. S., Torla, H. H. and Che

Man, Y. B. (2009). Extraction and characterization of gelatin from different marine fish Species in Malaysia. International Food Research Journal 16: $381-389$ (2009): Kuala Lumpur

9. Lawrence, P.K. and Koundal, K.R. (2002). Plant protease inhibitors in control of phytophagous insects. EJB Electronic J. of Biotech ISSN: 0717-3458. Vol.5 No.1, Issue of April 15, 2002.

10. Liu, D.C., Lin, Y.K.; Chen, M.T.(2011).Optimum condition of extracting collagen from chicken feet and its characteristics. Anim Biosci 2001;14(11):1638-1644. DOI: https://doi.org/10.5713/ajas.2001.1638

11. Liu, K. Markakis, P. (1989). An improved calorimetric method for determination antitryptic activity in soybean products. Vol.66, No.4, 1989415.

12. Mariod, A. A.; Abdelwahab, S. I.; Ibrahim, M. Y.; Mohan, S.; Elgadir, M. A. and Ain, N. M. (2011). Preparation and Characterization of Gelatins from Two Sudanese Edible Insects. J of Food Sc and Eng 1 (2011) 45-55.

13. Mariotto-Cezar,T.C.; Coelho, S.R.M.; Christ,D.; Schoeninger,V. and Almeida, A.J.B. (2013). Nutritional and antinutritional factors during the storage process of common bean.

14. Martins, B.C.; Rescolino,R.; Coelho, D.F.; Zanchetta, B.; Tambourgi,E.B.; Silveira,E. (2014). Characterization of Bromelain from Ananas Comosus Agroindustrial Residues Purified by Ethanol Factional Precipitation. Chemical Engineering Transactions, 37, 781-786 DOI: 10.3303/CET1437131.

15. Micheli, L.; Lucarini, E.; Trallori, E.; Avagliano, C.; De Caro, C.; Russo, R.; Calignano, A.; Ghelardini, C.; Pacini, A.; Di Cesare Mannelli, L. (2019). Phaseolus vulgaris L. Extract: Alpha-Amylase Inhibition against Metabolic Syndrome in Mice. Nutrients 2019, 11, 1778 . 
16. Mori, T.; Maruyamal, N.; Nishizawa, K.; Higasa, T.; Yagasaki, k.; Ishimoto, M. and Utsumi, S. (2004). The composition of newly synthesized proteins in the endoplasmic reticulum determines the transport pathways of soybean seed storage proteins. The Plant J. (2004) 40, 238-249. doi: 10.1111/j.1365-313X.2004. 02204.x

17. Navarro, S. (2012). The use of modified and controlled atmospheres for the disinfestation of stored products. J Pest Sci (2012) 85:301-322. DOI 10.1007/s10340-012-0424-3.

18. Nkunda, D.S. (2018). Effect of Purdue Improved Crop Storage (PICS) Bags on the Quality of Stored Beans (Phaseolus vulgaris). IJASR). ISSN (P): 2250-0057; ISSN (E): 2321-0087. Vol. 8, Issue 2 Apr 2018, 49-54.

19. Oliveira, A.P.; Andrade, G.F.; Mateó, B.S.O. and Naozuka, J. (2017). Protein and Metalloprotein Distribution in Different Varieties of Beans (Phaseolus vulgaris L.): Effects of Cooking. Intl J. of Food Sc. Vol 2017, Article ID 5957178, 8 pages. Retrieved December 28, 2020 from https://doi.org/10.1155/2017/5957178.

20. Petry, N.; Boy, E.; Wirth, J.P.; Hurrell, R.F. (2015) Review: The Potential of the Common Bean (Phaseolus vulgaris) as a Vehicle for Iron Biofortification. Nutrients 2015, 7, 1144-1173.

21. Saboury, A.A. (2009). Enzyme Inhibition and Activation: A General Theory J. Iran. Chem. Soc., Vol. 6, No. 2, June 2009, pp. 219-229.

22. Shyni, K; Hema, G.S.; Ninan, G.; Mathew, S.; Joshy, C.G. and Lakshmanan, P.T. (2014). Isolation and characterization of gelatin from the skins of skipjack tuna (Katsuwonus pelamis), dog shark (Scoliodon sorrakowah), and rohu (Labeo rohita). Food Hydrocolloids (39), 68-76. 

